\title{
Religious and Professional Beliefs of Schoolteachers - A Literature Review of Empirical Research
}

\author{
Nastja Häusler \\ University of Erlangen-Nürnberg \\ Nürnberg, Germany \\ Manfred L. Pirner ${ }^{1}$ \\ University of Erlangen-Nürnberg \\ Nürnberg, Germany \\ Annette Scheunpflug \\ University of Bamberg \\ Bamberg, Germany \\ Stephan Kröner \\ University of Erlangen-Nürnberg \\ Nürnberg, Germany
}

\begin{abstract}
We review empirical studies on possible relations between schoolteachers' personal religious beliefs or worldviews and their professional thinking and acting. The major underlying assumption of such research is that teachers' religiosity or worldview orientation has an impact on their teaching. Although this assumption has been the basis of much public dispute on various issues, there has been little scholarly attention to and empirical research on this field - particularly in Europe. This review aims to present, summarise and systematise relevant recent studies and discourse. After some theoretical reflections we firstly explore empirical research on how teachers' religiosity and worldview in general is related to their teaching. We secondly focus on studies on relations between religious beliefs in particular and science teaching. As two special constellations, research on teaching religion as a subject and studies on teaching in faith-based schools are reported. Finally, studies on the relationship between teachers' religious or worldview beliefs and their job-related self-regulation or coping are presented.
\end{abstract}

Keywords: teachers' beliefs; religious beliefs; teacher; teaching; religiosity; spirituality.

${ }^{1}$ Corresponding author: Manfred Pirner, manfred.pirner@fau.de 


\section{Introduction: Theoretical reflections on teachers' professional and religious beliefs}

Teachers' religious or worldview beliefs are often assumed to impact their way of teaching. Public debates in Western countries about teachers wearing headscarfs, about evangelical science teachers refusing to teach evolution theory or about confessional requirements of teachers at faith-based schools indicate that this assumption has societal and political implications. There is also a fierce debate on whether connections between teachers' religious or worldview beliefs and their professional thinking and acting should be viewed as legitimate at public (state) schools that are obliged to be 'neutral' regarding religion and worldviews - while the scarce articles in various journals do not provide much empirical knowledge about the existence or the nature of such connections. Thus, a review of empirical evidence regarding links between teachers' religious or worldview beliefs on the one hand and their profession-related beliefs on the other hand is needed. This is the aim of the present study. For this purpose, we will start with defining our central concepts, teachers' beliefs (or professional beliefs) and religious or worldview beliefs.

\subsection{The concept of teachers` beliefs}

Following Pajares (1992) as well as Buehl and Beck (2015, p. 66) the general psychological understanding of "belief" can be described as "an individual's judgment of the truth or falsity of a proposition" (Pajares, 1992, p. 316). Although it has repeatedly been pointed out that "belief" is a "messy construct" (Pajares, 1992; Hofer \& Bendixen, 2012, p. 230; Fives \& Buehl, 2012, p. 471), the notion of "teachers' beliefs" as beliefs related to teachers' professional activity has come to be firmly established in educational science over the recent decades. Research on these beliefs has developed into a field of its own, as signified by the publication of an International Handbook of Research on Teachers' Beliefs in 2015, edited by Helenrose Fives and Michele Gill. In the introduction to the Handbook Gill and Fives claim that "the importance of teachers' beliefs is evidenced by decades of research [...]" (Gill \& Fives, 2015, p. 1). Teachers' beliefs may be explicit or implicit, they show a certain degree of stability over time and are regarded as embedded into "a complex, interconnected, and multidimensional system within which they may be primary or derivative (i.e., grounded in primary beliefs), core or peripheral (i.e., endorsed with more or less conviction)" (Buehl \& Beck, 2015, p. 66). In this context, Fives and Buehl point to a characteristic research deficit: "Despite the widespread agreement that teachers' beliefs exist in a system, few empirical investigations have examined beliefs as complex systems" (Fives \& Buehl, 2012, p. 477). In the same vein, McAlpine, Eriks-Brophy and Crago (1996, p. 392) contend that "educational beliefs are a substructure of the total belief system [of a person] and must be understood in terms of their connections to other, perhaps more influential, beliefs". These can be seen to prominently include teachers' religious or worldview beliefs however little attention they have received in teacher research. In their thorough literature review, Fives and Buehl (2012, p. 472) found "that the topics of teachers' beliefs could be framed to include beliefs about (a) self, (b) context or 
environment, (c) content or knowledge, (d) specific teaching practices, (e) teaching approach, and (f) students". Moreover, they suggest that teachers' beliefs fulfil a threefold function: They may be used by teachers to (1) filter and interpret information, (2) frame a specific problem or task, and (3) guide immediate action (Fives \& Buehl, 2012, p. 478). In another literature review focused on the relationship between teachers' beliefs and their actual practices, Buehl and Beck (2015, p. 73-79) point out internal as well as external factors promoting or hindering the enactment of beliefs. Among the internal factors they count "knowledge", "self-awareness and self-reflection", and "other beliefs". Their findings clearly indicate that the impact of teachers' beliefs on their practices cannot be seen as direct and unidirectional, but as mostly complex, dialectical and reciprocal.

\subsection{The concept of religious and worldview beliefs}

In scholarship on religion such as religious studies, sociology of religion, psychology of religion, philosophy of religion, or theology, religious beliefs are usually conceptualized as a basic dimension of the complex construct of "religion", or of "religiosity" understood as "the individual, subjective aspect of the religious" (Bochinger 2004, p. 413; see Smart, 1996, for a classic example of such multidimensional theories and Huber \& Huber, 2012, for a more recent concept). In this context, religious beliefs refer to the doctrinal or ideological content of a religion (or religiosity) that is usually closely connected with the dimensions of religious practices, moral conduct and social relations or community. These beliefs are "religious" in that their content refers to a sacred or divine reality of some kind and by doing so offers a comprehensive, meaningmaking view of the world and human life in it (Smart, 1996; Clouser, 2005). The term "worldview" (German: "Weltanschauung") - that will sometimes also be used in this essay - denotes beliefs that offer such all-encompassing interpretations of the world and human life, while they may or may not refer to sacred or divine realities. Thus, "worldview" can be regarded as an umbrella term covering religious and non-religious comprehensive beliefs such as atheistic humanistic views or ideologies like Marxism or scientism (see e.g. Smart, 1999; Laeyendecker, 1996).

Religious beliefs as well as religiosity may not necessarily be linked to a formal or informal affiliation to one specific religion, but may draw on various religions and worldviews and refer to rather vague ideas of the sacred or transcendent. In these cases, scholars - but also respondents in empirical research - tend to speak of "spiritual beliefs" or "spirituality" to indicate a certain distance against institutionalized religion (see e.g. Pickel \& Sammet, 2011; Gräb \& Charbonnier, 2008; Bucher, 2007).

\subsection{Relations between religious and professional beliefs}

As to religious beliefs, the theological logic of all major religions seems to be quite clear: As explained above, religions claim to provide a comprehensive, allencompassing view of the world and a normative claim on one's whole life. 
Therefore, religious views or norms are expected to guide the believer's whole life, not only a religious segment of it - which, of course, includes his or her professional life. For Christians, this claim is, for instance, expressed in the New Testament Letter to the Colossians: "And whatsoever ye do, in word or in deed, do all in the name of the Lord Jesus, giving thanks to God the Father through him" (Col. 3:17, English Revised Version).

From a psychological perspective, this religious claim implies the ideal of a high degree of coherence of the believer's thinking and acting, because the religious beliefs are expected to be at the centre of his or her overall belief system and thus should dominantly guide all other beliefs. Placing religious beliefs at the core will help believers to minimize cognitive dissonance resulting from inconsistency between diverse beliefs.

However, already classic (Protestant) theological traditions like Martin Luther's two kingdoms doctrine (see e.g. Bornkamm, 1966) have developed the insight that religious beliefs which may be valid for the life of the church or one's personal life cannot be directly and in the same way applied to the realm of public, social and political responsibility. They must rather be translated or transformed in a way that does justice to the specific context. For example, you cannot rule a state just by the commandment to love your neighbor - nor can you manage a classroom solely by this ethical principle. Yet, in both cases actors can try to translate Christian principles into actions that serve the common good and express appreciation for every single human being. Theological concepts from Christian social ethics or public theology take account of such insights (see e.g. Lesch, 2013; Pirner et al., 2019).

This fits with insight from present-day neuropsychologists that humans are "consistently inconsistent" due to their compartmentalized beliefs and values (Kurzban, 2010, p. 4). Along the same line Buehl and Beck claim for teachers' beliefs that within an individual's belief system beliefs may "be held in clusters, that are more or less isolated, thereby allowing incompatible or inconsistent beliefs to coexist" (Buehl \& Beck, 2015, p. 66). These theoretical deliberations and hints advise caution against too simple and unidirectional hypotheses about causal connections between teachers' religious or worldview beliefs and their professional thinking and acting.

\section{Method}

As empirical research evidence of relations between teachers' religious or worldview beliefs and their professional thinking and acting is rare as well as little noticed, this essay aims to offer a literature review of recent empirical findings as a basis for much needed further research.

The literature search for our review was conducted in Janurary 2019. We used the query string ((ABS (teacher* AND belief* AND relig* OR spirit*) AND TITLE (teacher* OR belief* AND relig* OR spirit*)) in Scopus and the query string (descriptor: "teacher" AND "belief" AND "religion" OR "spirit") in ERIC. We furthermore restricted this search to the areas of social science, psychology, religious studies and educational science and to the articles published between 
2008 and 2018. In Scopus, the search query resulted in 74 papers. From ERIC, we got 406 results.

These papers were screened regarding relevance to our topic. To be included, a paper had to focus on the relation of teachers`religiousity/spirituality and their professional beliefs. Furthermore, it had to provide data that go beyond single case studies or small convenience samples. In a consecutive screening process, we first excluded all papers that could be judged irrelevant from the title. In a second step, we analysed the abstracts of all remaining papers and again excluded all obviously irrelevant papers. For the remaining papers, we sifted the actual articles. This screening process resulted in an exclusion of 62 papers from the Scopus search and 395 papers from the ERIC search. As there were 8 overlapping papers resulting from both searches, this resulted in 15 relevant papers from the database search. These papers were used as the starting point for a cross-reference analysis which provided 18 additional papers. Thus, we identified a total of 33 relevant papers, which are marked by an asterisk in the reference list. The selection process is illustrated by figure 1 .

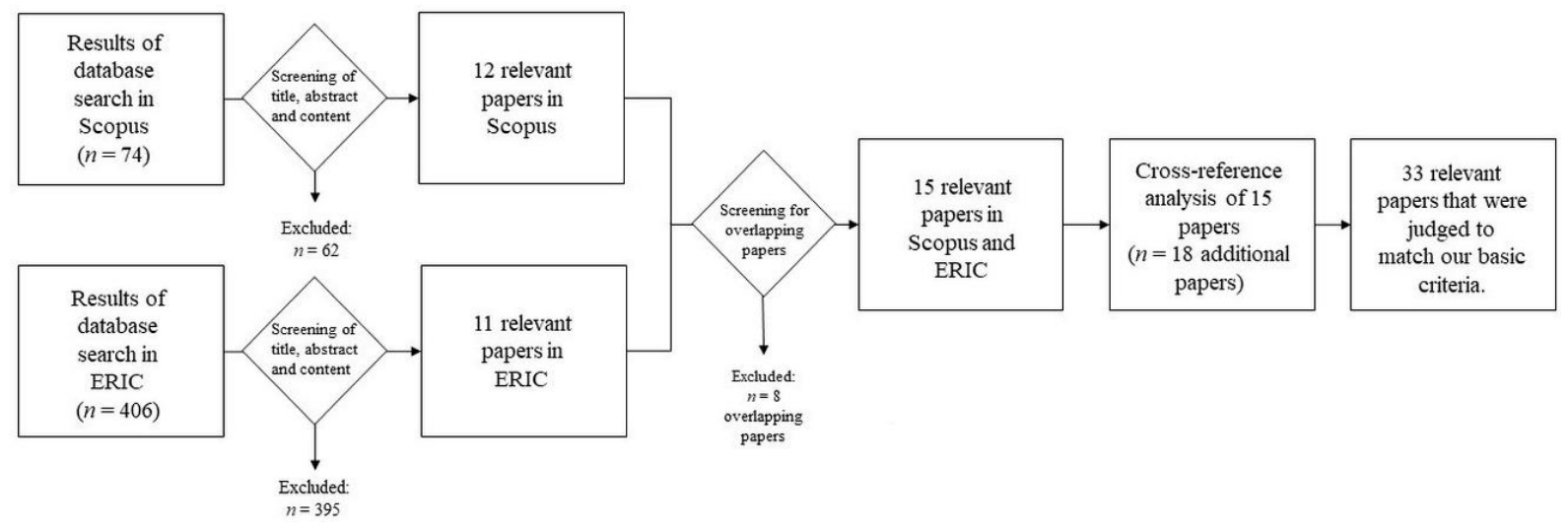

Figure 1. Literature search and selection process

In the following chapters, we give an overview of the current state of research regarding the relation between teachers' religious or worldview beliefs and their professional orientations as reported in the papers identified in our literature search. To this end, we will first focus on empirical studies on this relation in general (section 3). During the screening of our search results, we found that three areas stood out as research fields with special contexts as well as characteristic cross-reference networks, which means that scholars tend to intensely reference each other within these fields. Therefore, we will report on these fields in separate sections. The first of these research "hot spots" (Kröner, Penthin, \& Christ, 2019) deals with the relation between science teaching and teachers' religious or worldview beliefs, which is influenced by the characteristic fundamental tensions between science and religion (section 4). Section 5 will be devoted to research on teachers of religion-related school subjects such as religious studies, world religions, or religious education (RE), who can be assumed to exhibit a personal affinity towards religion that was part of their motivation for choosing to teach this school subject. Also, the context of a religion-related school subject may encourage these teachers to bring in their personal religious views into classroom discussion. Section 6 will report on research about teachers within the special context of faith-based schools that can 
also be assumed to promote positive relationships between teachers' religious beliefs and their professional thinking and acting. Furthermore, section 7 is devoted to research on links between teachers' religiosity and their selfregulation and coping. We will conclude by summarizing and assessing the reported state of research and by pointing to tasks for future research.

\section{Teachers' religious or worldview beliefs and their professionalism}

The research presented in the following section focuses on teachers' religious and worldview beliefs and its relation to teachers' professional beliefs in general. As mentioned above, most studies on teachers' religious beliefs originate from the US. Because even there, research evidence is scarce, we also refer to research on teachers at higher education institutions as well as to research on teacher students in the following account.

In 2007, Gross and Simmons examined the religiosity of American college and university professors in a representative poll $(\mathrm{N}=1471$, weighted). They report that these professors tend to be less religious than the American average: $31.2 \%$ of them regard themselves as nonreligious; $76.6 \%$ indicate to believe in God, compared to over $90 \%$ of the general population (Gross \& Simmons, 2007 p. 4). According to another survey, conducted in the preceding year by the American Higher Education Research Institute (HERI) $(\mathrm{N}=40.670), 81 \%$ of all college professors regard themselves as a "spiritual person", $64 \%$ as a "religious person", and $61 \%$ say that they pray or meditate (HERI, 2006, p. 3). Furthermore, this study found that high spirituality levels were positively correlated with certain pedagogical orientations like "Focus on Students' Personal Development", "Student-Centered Pedagogy", "Civic-Minded Practice and Civic-Minded Values" and "Positive Outlook in Work and Life" (HERI, 2006, p. 7).

There is also empirical evidence for the significance of teachers' religiosity at US state primary and secondary schools. A high percentage of schoolteachers understand teaching as their "calling in life" (about $45 \%$ according to Serow, 1994 and 59 \% according to Hartwick, 2007). This calling mostly has a religious dimension ("being called by God to teach"). It seems to be fuelling a high commitment and can be seen as an indicator of the consistently reported fact that teachers "work hard to integrate personal and professional identities" (Sikkink, 2010, p. 162). Serow (1994) reports that teacher students who feel called to become teachers show significantly higher confidence that teachers can contribute to social change, a greater desire to help others and higher appreciation for the work with young people. In European teacher research the feeling of "being called to teach" does not occur in usual teacher research (see e.g. Rothland, 2011, p. 285).

A number of mainly qualitative studies show that religious teachers experience their faith as an important source of their professional motivation and as guidance for their professional thinking and acting that helps them to be empathic, caring and appreciative towards their pupils as well as their colleagues (Baurain, 2012; Kang, 2009, Nelson-Brown, 2007; Pajak \& Blasé, 1989).

Beside such positive effects of religion and religiosity, a few teachers also describe conflicts and negative impacts of religion in professional contexts, e.g. 
problems with combining congregational activities and professional life as well as tensions and dissonances in dealing with students, parents or colleagues (Pajak \& Blasé, 1989; Barrett, 2015). Baurain (2012) also found that "numerous participants discussed the tensions involved in striking a balance between high academic standards and humility or flexibility in specific situations" (p. 325). From the sample drawn in her research Lipmen (2017) presents the example of a male teacher who feels a tension between his atheistic belief and his dominantly Christian professional environment. He also mentions that there is "a quiet 'Pagan Coalition' of teachers at school' (Lipmen, 2017, p. 106).

In summary, research findings revealed some evidence of relations between teachers' religiosity or spirituality and their professional orientation. Teachers' religiosity appears to be linked to their work commitment and motivation, as well as to certain views on teaching and learning. A teachers' religious orientation may therefore influence the way he or she interacts with pupils, colleagues or parents. While teachers' religiosity may well be a source of motivation and commitment, it has also been noted as a potential source of professional conflict.

\section{Religious beliefs and science teaching}

Although there is not much research about the general relation between teachers' religious and professional beliefs, a characteristic international research strand focuses on relations between teachers' personal religious beliefs and their attitude towards science, their knowledge and their science teaching. In our literature search, 19 studies explicitly addressed this relationship, which can be seen to mirror the general interactions and tensions between scientific and religious beliefs in public debate and is exemplary for discovering interactions of beliefs in the context of teachers' belief systems.

The most comprehensive survey in this field has been published by French biologist Pierre Clément (2015). He conducted a large-scale study on teachers' conceptions concerning evolution and the relationship between science and religion in 30 countries with more than ten thousand teachers. It turned out that in predominantly Islamic countries (Algeria, Senegal, Morocco, Lebanon and Tunisia) very small percentages see the origin of life as a result of natural phenomena only, while high percentages believe that God was involved in creation (over $70 \%$ take a creationist stance). However, in countries with high degrees of Christian religiosity (including Cameroon, Gabon, Georgia, Malta, Burkina Faso, Poland, Romania, South Africa, Cyprus and Brazil) the majority believe in creation by God, too, either in combination with or instead of evolution. Teachers from western and northern European countries as well as from Australia and South Korea (the USA were not part of the sample) demonstrated a preference for believing that the origin of life came without God.

Clément highlights that there are considerable international differences even among biology teachers: "Even for biologists, the percentage of radical creationist conceptions [...] varies from $0 \%$ (Denmark) or $1 \%$ (Spain, France) to $87.5 \%$ in Algeria" (Clément, 2015, p. 283). In 17 countries the answers of the biology teachers do not significantly differ from the answers of their colleagues, 
while in the remaining 13 countries the difference is significant - the percentage of radical creationist beliefs is lower, but also the percentage of adherents to the compromise item "The origin of life may be explained by natural phenomena that are governed by God." (p. 283)

Another remarkable result is that differences between countries persist even when teachers of the same religion or denomination are compared, while there are mostly no significant differences between teachers from different religions within one country. Clément concludes that obviously it is difficult "to change the teachers' conceptions that are deeply rooted in the socio-cultural and historical context of their own country" (Clément, 2015, p. 286). However, he also points to the quite high percentages in almost all countries of those who regard belief in God and in natural evolution to be compatible.

A considerable number of country-specific studies have provided additional and partly differentiated evidence of the tension many science teachers feel between religion and science as well as concerning their own concepts in this respect (see e.g. for Brazil El-Hani \& Sepulveda, 2010, as well as Bagdonas \& Silva, 2015; for Germany Fuchs, 2010; for South Africa Govender, 2017; for Sweden Hansson \& Redfors, 2007).

While the US was not included in Clément's study, it harbors a long tradition of controversial public dispute about evolution theory and creationism in public schools that has generated a lengthy list of academic contributions on this topic (e.g. NAS, 2008; Laats \& Siegel, 2016). Although a recent opinion poll among the US population shows creationist views at a new low, it is still $38 \%$ who believe "that God created humans in their present form at some time within the last 10,000 years or so" (Swift, 2017). Just as in such general polls research on teachers' beliefs, too, suggests that the strength of their religious conviction is negatively related with acceptance of evolution and that it is difficult for many but not all - teachers to harmonize scientific knowledge about evolution with their religious beliefs (Tatina, 1989; Trani, 2004; Levesque \& Guillaume, 2010). One study among Wisconsin biology teachers was able to show that a majority of almost $83 \%$ regarded belief in God and acceptance of evolution theory to be compatible (van Koevering \& Stiehl, 1989). However, in their inquiry of 375 female teacher education students at California State University Levesque and Guillaume (2010) found that, contrary to their hypotheses, the students' acceptance of evolution theory was not higher than that of women in national opinion polls, and only a small minority of religious students "were able to reconcile their religious faith with the theory of evolution" (p. 352).

In an Islamic context, Mansour (2008a) examined 75 Egyptian science teachers and found "that personal religious experience is one of the most influential social factors on the experience of science teachers [...] and that this [...] influences teachers' pedagogical beliefs and practices" (Mansour, 2008a, p. 558). Mansour developed a "personal religious beliefs model" (PRB), which puts teachers' experiences, pedagogical beliefs, practices and identity in relation to their religious beliefs and thus incorporates religious beliefs as a component of teachers' professionalism (Mansour, 2008a, p. 565; 2008b). In recent studies Mansour provided additional evidence that underscores the necessity to include science teachers' religious views in teacher education (Mansour, 2011; 2015). 
The challenges arising for science teachers from the intersection between their personal religious beliefs and their profession have been discussed and empirically researched in mainly two aspects.

First, some studies have explored the consequences of the teachers' beliefs for their teaching. For instance, Bagdonas and Silva (2015) point to the problematic finding that most science teachers do not feel competent to conduct classroom discussions on the topic of conflicts between religious views and scientific knowledge and therefore avoid such discussions. More concretely, Stolberg (2007) has been able to show that teachers' understanding of the relationship between science and religion has consequences for their concepts of science teaching. In an empirical study with 92 pre-service primary teachers in England she found that those who saw science and religion as different but equally valid approaches to reality tended to prefer significantly more open, non-directive teaching methods that grant pupils the freedom of forming their own thoughts and judgements than their colleagues who did not see science and religion as equally valid (Stolberg, 2007, pp. 924-927).

Second, a number of studies inquire into consequences for teacher education and further training. It has become clear from the reported research that concepts on the religion-science-relationship obviously are not easy to change because they are connected with personal religious or worldview beliefs. Several authors therefore have advocated and empirically tested strategies that aim to stimulate a "conceptual change" in teacher students or teachers. Such didactical strategies are mainly (a) explicit discussion of students' religious views in university seminars or teacher training courses, (b) integration of historical knowledge about the developing relationship between religion and science, and (c) inclusion of philosophical, in particular cosmological and epistemological reflection on the nature of science (see e.g. Reiss, 2014; 2017; Govender, 2017).

There is some evidence that the impact of teachers' religious or worldview beliefs on their subject teaching is not limited to the subject of science, although empirical studies are widely missing in those other areas. For the subject history in US schools, Barton and James (2010) point to the problem that teachers often omit serious attention to religion because of their uncertainty concerning legal and didactical questions. Chan and Wong (2014) have shown that religious beliefs even interact with mathematics teachers' understanding and teaching of their subject.

As indicated in the introduction, in the following, we will proceed by examining two special constellations. Both of them refer to teachers whose professional context is already religiously primed. In one case it is teaching the school subject of religious studies or religious education that shapes teachers' professional context; in the other case it is working at a faith-based school that creates a religiously informed context. It can be assumed that in both contexts teachers may display higher religiosity scale values and report stronger religious beliefs than teachers in other contexts and that teachers in these specific contexts may be prone to link their religious and professional beliefs. 


\section{Religious beliefs and teaching religion as a subject}

When it comes to teaching "religion", "religious studies", "world religions" or "religious education" (=RE) as a course or school subject, it seems quite obvious to assume that teachers' personal religious or worldview beliefs matter. However, a distinction must be made concerning the concept of teaching in question. In a multi-faith, religious studies-based approach of RE, like in the UK or in world religion courses at US-American schools, teachers are required to hold back their personal religious views in order to be "fair", "unbiased" and "neutral" towards all religions and worldviews. In a confessional type of RE based mainly on theological perspectives, like in Germany, teachers are officially allowed to bring their own confessional and personal views into classroom discussion and emphasize one religion or denomination - however, without indoctrinating or hassling pupils and without devaluing other religions or worldviews. In the following we will present one exemplary study from the US context and summarize some findings from the German context; a study with $\mathrm{RE}$ teachers in the UK is presently under way. (cf. https://www.jubileecentre.ac.uk/1755/ projects/current-projects/religiouseducation-teachers)

Anderson, Mathy, and Cook (2015) examined the relationship between teachers' personal beliefs and knowledge of world religions on the one hand and their teaching of world religions on the other hand on a sample of 22 elementary preservice teachers (PST) using a mixed method approach (p. 268). They discovered that only "a few PSTs acknowledged that their beliefs on religion might impact how they design and deliver their lessons" while the majority did not (p. 277). Another finding was that "the PSTs' word choice frequently was biased toward Christianity" and that "there were a number of ways the PSTs exhibited a Christian bias in their teaching, some subtle and unrecognized, and others more blatant" (p. 279). Only few teachers were capable of recognizing and reflecting about this biased-based manner of teaching, even though many of them intended "to teach in an unbiased manner" (p. 277).

Several German studies have explored the relationship between RE teachers' "lived religion" and the "taught religion". In a mixed methods study in the German state of Northrhine-Westfalia Feige, Dressler, Lukatis, and Schöll (2000) found that what RE teachers pass on to the pupils in class is mostly not their "authentic" personal religion, but rather a decidedly school-conform "educational religion" ("Bildungsreligion", Feige, 2001, p. 296). This form of religion is indeed connected with the biographically informed subjective religiosity of the teachers, but even more it is the result of their "individual reflection processes", which can be regarded as a constitutive part of their professionalism as RE teachers. Biesinger, Münch, and Schweitzer (2008) have confirmed and further differentiated this finding in their qualitative studies on RE teachers in Baden-Württemberg. In their study in the German state of Hessen, Heimbrock (2017) and his team were able to show that RE teachers may feel tensions between their religious beliefs or theological perspectives (e.g. God's unconditional grace) and professional requirements (e.g. grading and punishing pupils). With reference to this study Pirner (in Pirner \& Wamser, 2017; Pirner, 2019) has elaborated patterns of how RE teachers perceive and deal 
with these tensions, which can be seen as different stages of what he calls RPR competence (competence to relate pedagogical and religious rationality).

\section{Teachers' religious beliefs at faith-based schools}

Similar to teachers of RE, teachers at faith-based schools work in a religionfriendly context that can be assumed to promote their "taking their faith to work" (Sikkink, 2010). Research literature on faith-based schools is vast and hard to oversee. As result of an extensive meta-analysis, including 90 studies on US schools, Jeynes (2012) summarizes: “This meta-analysis indicates that students who attend religious schools perform better than their counterparts who are in public schools." (p. 324). The teachers' educational practices are discussed as reasons. It appears "that teachers from faith-based schools are more demanding and expect higher levels of attainment from their students of equal status. In addition, it appears that the achievement gap is narrower at faith-based schools than it is at traditional public schools." (p. 326). Jeynes points to further possible explanations partly given by other authors such as the religious teachers' tendency to view every student as a unique human made in the image of God, or the sense of purpose in life, which is often associated with faith, that is conveyed to the students.

In a literature review of US-American research on faith-based schools, Sikkink (2010) has arrived at similar estimations as Jeynes. In addition he emphasizes the necessity to differentiate between different religions, denominations and theological strands within the Christian school sector. For instance, research evidence shows that teachers at Catholic schools are especially strongly perceived by their students as personally responsible and authoritative leading figures (Sikkink, 2010, p. 160; see also Hunt, Joseph, \& Nuzzi, 2004). Teachers at fundamentalist and evangelical (Protestant) schools have to conform with these schools' partly strong endeavors to spiritualize the whole every-day school life and to emphasize structure, discipline and instructivist methods (Sikkink 2010, p. 171).

As an example of a European country, in Germany, with more than 2,000 faithbased private schools - most of them either Catholic or Protestant - research results are not as distinct as in the US. It is not even certain that teachers at faithbased schools show an average higher degree of religiosity compared to the general population (Pirner, 2008; Pirner, Scheunpflug, \& Holl, 2010, p. 197). As to student performance, Standfest, Köller, and Scheunpflug (2005, summarized in Scheunpflug, 2011, pp. 413-414) found little differences to normal state schools, except for a better school climate and a better teacher-pupilrelationship. In analogy to US findings, the studies by Pirner (2008) und Holl (2011) show that teachers at faith-based Christian schools describe their ethos as guided by love of neighbor, individual care for the God-created child and an emphasis of pedagogical, educational tasks over against teaching tasks. Also, in Germany, too, teachers at evangelical schools more deliberately create links between their personal religious faith and their profession and are also better able to communicate about these links (Holl, 2011; Lehmann, 2015). 
Finally, we will now take a closer look at another important aspect of research on relations between teachers' religious or worldview beliefs and their professionalism: the potential of religiosity as a resource for coping with difficult situations and professional challenges.

\section{Religious beliefs and coping among schoolteachers}

It is beyond dispute that the job of a schoolteacher is a demanding and straining profession with a rather high risk of burnout (see e.g. Seidel, 2014; Stanley, 2014). In face of numerous studies that provide evidence for relations between health, life satisfaction and self-regulation on the one hand and religiosity or spirituality on the other hand (see for recent overviews Oman, 2018; Koenig, 2011), it seems quite surprising that religiosity and spirituality have received little attention in empirical research on teachers' stress experience, their self-regulation and coping.

Winograd (2009) reports that for several Afro-American female teachers in the US their religious beliefs and spiritual practice significantly help them to cope with difficulties in their teaching profession. On the basis of 22 in-depth interviews with German school teachers Bohnsack (2009) has concluded that teachers' religiosity - with its central aspect of "existential confidence" - can be an important factor of self-stabilization and can motivate them to stabilize the personality of their pupils, too. Green (2017) found ambivalent results among 377 US public school teachers suffering from chronic pain. Positive religious or spiritual coping strategies moderated pain reports for those teachers with high levels of stress; however, at lower levels of stress, positive religious or spiritual coping was associated with increased pain reports. In a recent study from Italy among 80 female lay and consecrated teachers of primary school, preschool and Kindergarten Chirico (2017) identifies positive correlations between church attendance and the well-being dimensions of personal accomplishment, job satisfaction and perceived performance as well as negative correlations with turnover intention and sickness absence (pp. 845-847). In a study from Iran Najafi and Jafari (2015) found significant interrelations between characteristics of happiness and religiosity among 250 elementary school teachers. And Gibson (2014) reports about an investigation into possible effects of principals' spirituality at three public primary schools in New Zealand. According to his summarized results the three principal participants "believed their personal meanings of spirituality were intentionally and yet appropriately interwoven into a range of professional tasks, linked to characteristics of servant, transformational, moral and relational leadership styles, and contributed to their sense of resilience in the job." (p. 520).

The reported studies indeed seem to support the idea that religious beliefs and spiritual practices contribute to teachers' well-being and may prevent burnout. However, it should be remembered that some research evidence presented above indicates that teachers may also feel tension or conflict between their religious or worldview beliefs and the requirements of their profession (Barrett, 2015; Lipmen, 2017), which may lead to increased stress and strain. 


\section{Conclusion}

This literature review has supported our initial assumption of a relationship between teachers' religious and professional beliefs. The reviewed studies have shown that most of the research in this area can be found in the US - and some other countries with high levels of religiosity -, while it has been widely neglected in European countries. It has also become clear that because of the more secular character of the latter, results from US studies cannot simply be transferred to European contexts - although there are some intercultural commonalities in the research results (e.g. concerning evangelical teachers and teachers at faith-based schools). Among the research subtopics, the tension between religious beliefs and scientific views has received most attention internationally as it appears to be a pressing issue for many science teachers. Again, this seems to be not as urgent an issue in most European countries.

On the whole, the authors of the reviewed studies seem to favor the idea that the relations between teachers' religious or worldview beliefs and their professional thinking and acting can be widely interpreted as religious or worldview beliefs influencing professional beliefs, reflection and acting. Most convincing evidence for this view comes from the qualitative case studies included in our review.

Three major dimensions of such possible impacts can be distinguished:

a) the educational (social and relational) dimension concerning how teachers deal with their pupils or colleagues and promote the young people's personality development;

b) the didactical dimension concerning curricular choices, teaching objectives and methods;

c) the psychological dimension concerning teachers' self-regulation, coping, and health management.

In all three areas, religious and worldview beliefs obviously can have not only positive, but also problematic impacts. They can serve as valuable resources for the teaching profession, but can also impair and inappropriately interfere with teachers' educational and didactical tasks. In our opinion, this is precisely the reason why relations between teachers' religious or worldview beliefs and their professional thinking and acting should be further elucidated by intensified research and should become a standard object of reflection in teacher education and training.

Limitations of the reviewed studies often lie in a qualitative methodology that exclusively relies on the teachers' self-reports, while classroom observation and cross-checking interviews with students or analyses of students' competence development are nearly absent from the reviewed research and should be integrated into future investigations in this area. In several quantitative studies the conceptualizations of religiosity could have wished to be more complex and multidimensional. As already mentioned in the introduction, the scientific investigation of religiosity and religious or worldview beliefs has to take into account the complex nature of the subject. The same holds for teachers' profession-related beliefs, which also suffer from a heterogeneous conceptualization across studies. Thus, future research should be more precise 
about which dimensions and manifestations of religiosity or religious and worldview beliefs relate in which way to which aspects of teachers' professional beliefs and patterns of action. Also, common theoretical frames of reference or at least shared theoretical perspectives would be helpful to promote the possibility of comparison, exchange and discourse. We have pointed to a few of them in our review. However, further steps into that direction should be taken in future studies.

\section{References}

Anderson, D., Mathy, H., \& Cook, T. (2015). Religious beliefs, knowledge, and teaching actions: elementary teacher candidates and world religions. Religion \& Education, 42(3), 268-288. doi: 10.1080/15507394.2014.944063

Bagdonas, A., \& Silva, C. C. (2015). Enhancing teachers' awareness about relations between science and religion. Science \& Education, 24(9-10.), 1173-1199. doi: 10.1007/s11191-015-9781-7

Barrett, S. E. (2015). Impact of religious beliefs on professional ethics: a case study of a new teacher. Canadian Journal of Education, 38(3), 1-21.

Barton, K. C., \& James, J. H. (2010). Controversy in the classroom. Religion in history and social studies. Perspectives on History. The Newsmagazine of the American Historical Association.

Baurain, B. (2012). Beliefs into practice: A religious inquiry into teacher knowledge. Journal of media and religion, 11(5), 312-332. doi: 10.1080/15348458.2012.723576

Biesinger, A., Münch, J., \& Schweitzer, F. (2008). Glaubwürdig unterrichten. Biographie Glaube - Unterricht. Freiburg i.Br.: Herder.

Bochinger, C. (2004): Religiosität. In Religion in Geschichte und Gegenwart (7) (pp. 413-414). Tübingen: Mohr Siebeck.

Bohnsack, F. (2009). Aufbauende Kräfte im Unterricht. Lehrerinterviews und empirische Belege. Bad Heilbrunn: Klinkhardt.

Bornkamm, H. (1966). Luther's doctrine of the two kingdoms in the context of his theology. Minneapolis, MN: Fortress Press.

Bucher, A. (2007). Psychologie der Spiritualität: Handbuch. Weinheim: Beltz PVU.

Buehl, M., \& Beck, J.-S. (2015). The relationship between teachers' beliefs and teachers' practices. In H. Fives, \& M. G. Gill (Eds.), International Handbook of Research on Teachers' Beliefs (pp. 66-84). New York: Routledge.

Chan, Y. C., \& Wong, N. Y. (2014). Worldviews, religions, and beliefs about teaching and learning: perception of mathematics teachers with different religious backgrounds. Educational Studies in Mathematics, 87(3), 251-277. doi: 10.1007/s10649-014-9555-1

Chirico, F. (2017). Religious belief and mental health in lay and consecrated Italian teachers. Journal of Religion and Health, 56(3), 839-851. doi: 10.1007/s10943-016-02427

Clément, P. (2015). Creationism, science and religion: A survey of teachers' conceptions in 30 countries. Procedia - Social and Behavioral Sciences, 167, 279 - 287. doi: 10.1016/j.sbspro.2014.12.675

Clouser, R. A. (2005). The myth of religious neutrality. An essay on the hidden role of religious belief in theories (revised ed.). Notre Dame, Indiana: University of Notre Dame.

El-Hani, C. N., \& Sepulveda, C. (2010). The relationship between science and religion in the education of protestant biology pre-service teachers in a Brazilian university. Cultural Studies of Science Education, 5(1), 103-125. doi: 10.1007/s11422-009-9212-7 
Feige, A. (2001). Die Religionslehrerinnen und -lehrer als Symptom der Entkoppelung von Kirche und Gesellschaft. Zeitschrift für Pädagogik und Theologie, 53, 289-296.

Feige, A., Dressler, B, Lukatis, W., \& Schöll, A. (2000). „Religion“ bei ReligionslehrerInnen. Religionspädagogische Zielvorstellungen und religiöses Selbstverständnis in empirischsoziologischen Zugängen. Münster: LIT.

Fives, H., \& Buehl, M. (2012): Spring cleaning for the messy construct of teachers` beliefs: What are they? Which have been examined? What can they tell us? In , K. R. Harris, S. Graham, and T. Urdan (Eds.), APA Educational Psychology Handbook: Vol. 2. Individual Differences and Cultural and Contextual Factors (pp. 471-499), American Psychological Association.

Fives, H., \& Gill, M. G. (Eds.). (2015). International Handbook of Research on Teachers' Beliefs. New York: Routledge.

Fuchs, M. (2010). Bioethische Urteilsbildung im Religionsunterricht: theoretische Reflexion empirische Rekonstruktion. Göttingen: Vandenhoeck \& Ruprecht.

Gibson, A. (2014). Principals` and teachers' views of spirituality in principal leadership in three primary schools. Educational Management Administration \& Leadership, 42(4), 520-535. doi: $10.1177 / 1741143213502195$

Govender, N. (2017). Physical sciences preservice teachers' religious and scientific views regarding the origin of the universe and life. International Journal of Science and Mathematics Education, 15(2), 273-292. doi: 10.1007/s10763-015-9695-5

Gräb, W., \& Charbonnier, L. (Eds.) (2008). Individualisierung - Spiritualität - Religion: Transformationsprozesse auf dem religiösen Feld in interdisziplinärer Perspektive. Münster: Lit.

Green, D. (2017). The moderating effects of positive religious/spiritual coping on teachers' pain and stress (Doctoral dissertation, Austin State University). Retrieved from https://scholarworks.sfasu.edu/cgi/viewcontent.cgi?referer=\&httpsredir=1\&articl $\mathrm{e}=1131 \&$ context $=$ etds

Gross, N., \& Simmons, S. (2007). How religious are America's college and university professors? SSRC Essay Forum. Retrieved from http://religion.ssrc.org/reforum/

Hansson, L., \& Redfors, A. (2007). Physics and the possibility of a religious view of the universe: Swedish upper secondary students' views. Science \& Education, 16(3-5), 461-478. doi: 10.1007/s11191-006-9036-8

Hartwick, J. M. M. (2007). The religious and prayer lives of public school teachers. In W. Jeynes, \& E. Martinez (Eds.), Christianity, Education, and Modern Society (pp. 129160). Charlotte, NC: Information Age Publishing.

Heimbrock, H.-G. (Hrsg.). (2017). Taking Position. Empirical studies and theoretical reflections on Religious Education and worldview. Teachers Views about their personal Commitment in RE Teaching. International Contributions. Münster: Waxmann Verlag.

HERI (Higher Education Research Institute). (2006). Spirituality and the professoriate. A national study of faculty beliefs, attitudes, and behavior. Retrieved October 26, 2018, from http://spirituality.ucla.edu/docs/results/faculty/spirit_professoriate.pdf

Hofer, B. K., \& Bendixen, L. D. (2012). Personal epistemology: theory, research, and future directions. In K. R. Harris, S. Graham, \& T. Urdan (Eds.), APA Educational Psychology Handbook: Vol 1. Theories, constructs, and critical issues (pp. 227-256). Washington, D.C.: American Psychological Association.

Holl, A. (2011). Orientierungen von Lehrerinnen und Lehrern an Schulen in evangelischer Trägerschaft. Eine qualitativ-rekonstruktive Studie. Münster: Waxmann.

Huber, S., \& Huber, O. W. (2012). The Centrality of Religiosity Scale (CRS). Religions, 3, 710-724.

Hunt, T.-C., Joseph, E.-A., \& Nuzzi, R.-J. (Eds.). (2004). Catholic schools still make a 
difference: ten years of research 1991-2000. Washington, D.C.: The National Catholic Educational Association.

Jeynes, W. H. (2012). A meta-analysis on the effects and contributions of public, public charter, and religious schools on student outcomes. Peabody Journal of Education, 87(3), 305-335.

Kang, S. J. (2009). 'I can't do it without my faith.' A mixed methods study of teachers' efficacy and personal religiousness. Paper presented at the Annual Meeting of the American Educational Research Association San Diego, April 13-18.

Koenig, H. G. (2011). Spirituality and health research: methods, measurements, statistics, and resources. West Conshohocken, PA: Templeton Press.

Kröner, S., Penthin, M., \& Christ, A. (2019). Forschungssynthesen zur Digitalisierung in der kulturellen Bildung. In B. Jörissen, \& L. Unterberg (Eds.), Forschung zur Digitalisierung in der Kulturellen Bildung. München: kopaed.

Kurzban, R. (2010). Why everyone (else) is a hypocrite. Evolution and the modular mind. Princeton, N.J.: Princeton University Press.

Laats, A., \& Siegel, H. (2016). Teaching evolution in a creation nation. Chicago: University of Chicago Press.

Laeyendecker, L. (1996). Weltanschauung. In E. Fahlbusch, J. M. Lochman, J. Mbiti, J. Pelikan, \& L. Vischer (Eds.), Evangelisches Kirchenlexikon: Internationale theologische Enzyklopädie (EKL) (3rd edition, Vol. 4, pp. 1254-1255). Göttingen: Vandenhoeck \& Ruprecht.

Lehmann, T. (2015). Evangelikal orientierte Schulen - geschlossene Systeme oder exemplarische Bildungsräume? Theoretische Hintergründe, bildungstheoretische Reflexionen und schulpädagogische Perspektiven. Münster: Waxmann.

Levesque, P. J., \& Guillaume, A. M. (2010). Teachers, evolution, and religion: no resolution in sight. Review of Religious Research, 51(4), 349-365. doi: $10.2307 / 20778528$

Lesch, W. (2013). Übersetzungen. Grenzgänge zwischen philosophischer und theologischer Ethik. Freiburg i. Br.: Herder.

Lipmen, S.-J. (2017). Inadvertent evangelisms (or not): teachers' views on religion, religious beliefs, positionality and presence and their influence on their curricular choices in the classroom (Doctoral dissertation, University of Southern California). Retrieved from https:// search.proquest.com/docview/1953259472

Mansour, N. (2008a). Religious beliefs: a hidden variable in the performance of science teachers in the classroom. European Educational Research Journal, 7(4), 557-576. doi: 10.2304/eerj.2008.7.4.557

Mansour, N. (2008b). The experiences and personal religious beliefs of Egyptian science teachers as a framework for understanding the shaping and reshaping of their beliefs and practices about Science-Technology-Society (STS). International Journal of Science Education, 30(12), 1605-1634. doi: 10.1080/09500690701463303

Mansour, N. (2011). Science teachers' views of science and religion vs. the Islamic perspective: conflicting or compatible? Science Education, 95, 281- 309. doi: $10.1002 /$ sce. 20418

Mansour, N. (2015). Science teachers` views and stereotypes of religion, scientists and scientific research: a call for scientist-science teacher partnerships to promote inquiry-based learning. International Journal of Science Education, 37(11), 1767-1794. doi: 10.1080/09500693.2015.1049575

McAlpine, L., Eriks-Brophy, A., \& Crago, M. (1996). Teaching beliefs in Mohawk classrooms: issues of language and culture. Anthropology \& Education Quarterly, 27, 390-413.

Najafi, F., \& Jafari, E. (2015). Investigating the relationship between religious beliefs and 
elementary teachers' happiness in the working environment. International Journal of Educational and Psychological Researches, 1(2), 171-178.

National Academy of Sciences (NAS). (2008). Science, evolution, and creationism: a view from the National Academy of Sciences. Washington, D.C.: National Academy Press.

Nelson-Brown, J. E. (2007). The keys of the kingdom. How teachers' religious identity impacts their experience of teaching. Dissertation Abstracts International, A: The Humanities and Social Sciences, 67(11), 40-84.

Oman, D. (2018). Why religion and spirituality matter for public health: evidence, implications, and resources. New York: Springer.

Pajak, E., \& Blasé, J. J. (1989). The impact of teachers' personal lives on professional role enactment. A qualitative analysis. American Educational Research Journal, 26(2), 283310.

Pajares, M. F. 1992. Teachers' beliefs and educational research: cleaning up a messy construct. Review of Educational Research, 62(3), 307-332.

Pickel, G., \& Sammet, K. (Eds.) (2011). Religion und Religiosität im vereinigten Deutschland. Zwanzig Jahre nach dem Umbruch. Wiesbaden: VS-Verlag für Sozialwissenschaft.

Pirner, M. L. (2008). Christliche Pädagogik. Grundsatzüberlegungen, empirische Befunde und konzeptionelle Leitlinien. Stuttgart: Kohlhammer.

Pirner, M. L., Scheunpflug, A., \& Holl, A. (2010). Lehrkräfte an Schulen in christlicher Trägerschaft im deutschen Sprachraum. Zum Stand der empirischen Forschung. Theo-Web. Zeitschrift für Religionspädagogik, 9(1), 193-209.

Pirner, M. L., \& Wamser, D. (2017). Religiosität und Lehrerprofessionalität. Zur Bedeutung von bildungstheologischen Überzeugungen und bildungstheologischer Reflexionskompetenz. In H.-G. Heimbrock (Ed.), Taking Position. Empirical studies and theoretical reflections on Religious Education and worldview. Teachers views about their personal commitment in RE Teaching. International contributions (pp. 111-126). Münster: Waxmann Verlag.

Pirner, M. L. (2019). Öffentliche Religionspädagogik. Religionspädagogik als Übersetzungsaufgabe?! In F. v. Oorschot, \& S. Ziermann (Eds.), Theologie in Übersetzung? (pp. 97-110). Leipzig: Ev. Verlagsanstalt.

Pirner, M. L., Lähnemann, J., Haussmann, W., \& Schwarz, S. (Eds.) (2019). Public Theology Perspectives on Religion and Education. London \& New York: Routledge.

Reiss, M. J. (2014). What significance does Christianity have for science education?. In M. Matthews (Ed.), Handbook of Historical and Philosophical Research in Science Education (pp. 1637-1662). Dordrecht: Springer Netherlands.

Reiss, M. J. (2017). Science education and ethics education in faith-based schools. In S. Khalili, F. Watts, \& H. Wiseman (Eds.), A 21st Century Debate on Science and Religion (pp. 192-207). Cambridge: Cambridge Scholars Publishing.

Rothland, M. (2011). Warum entscheiden sich Studierende für den Lehrerberuf? Interessen, Orientierungen und Berufswahlmotive angehender Lehrkräfte im Spiegel der empirischen Forschung. In E. Terhart, H. Bennewitz, \& M. Rothland (Eds.), Handbuch der Forschung zum Lehrerberuf (pp. 268-295). Münster: Waxmann.

Scheunpflug, A. (2011). Die Religionspädagogik als erziehungswissenschaftliche Disziplin - der Blick aus der Perspektive Allgemeiner Pädagogik. Zeitschrift für Pädagogik und Theologie, 63(2), 107-116.

Seidel, A. (2014, July 18). The teacher dropout crisis. NPR. [blog post]. Retrieved from http://www.npr.org/blogs/ed/2014/07/18/332343240/the-teacher-dropoutcrisis?utm_campaign $=$ storyshare\&utm_source $=$ twitter.com\&utm_medium $=$ social

Serow, R. C. (1994). Called to teach: a study of highly motivated preservice teachers. Journal of Research and Development in Education, 27(2), 65-72. 
Sikkink, D. (2010). Do religious school teachers take their faith to work? Research evidence from the United States. Theo-Web. Zeitschrift für Religionspädagogik, 9(1), 160-179. Retrieved from http://www.theo-web.de/zeitschrift/ausgabe-201001/12.pdf

Smart, N. (1996). Dimensions of the sacred. An anatomy of the world's beliefs. Los Angeles: University of California Press.

Smart, N. (1999). Worldviews. Crosscultural explorations of human beliefs (3 ${ }^{\text {rd }}$ ed.). New York: Pearson.

Standfest, C., Köller, O., \& Scheunpflug, A. (2005). Leben, lernen, glauben. Zur Qualität evangelischer Schulen. Münster: Waxmann.

Stanley, J. (2014). How unsustainable workloads are destroying the quality of teaching. Schools Week. Retrieved from http://schoolsweek.co.uk/how-unsustainableworkloads-are-destroying-the-quality-of-teaching

Stolberg, T. (2007). The religio-scientific frameworks of pre-service primary teachers: an analysis of their influence on their teaching of science. International Journal of Science Education, 29(7), 909-930. https://doi.org/10.1080/09500690600924934

Swift, A. (2017, May 22). In U.S., belief in creationist view of humans at new low. In Gallup News. Retrieved from https://news.gallup.com/poll/210956/beliefcreationist-view-humans-new-low.aspx

Tatina, R. (1989). South Dakota high school biology teachers and the teaching of evolution and creationism. The American Biology Teacher, 51, 275-280.

Trani, R. (2004). 'I won't teach evolution; it's against my religion. And now for the rest of the story'. The American Biology Teacher, 66, 419-427. doi: 10.2307/4451708

Van Koevering, T. E., \& Stiehl, R. B. (1989). Evolution, creation and Wisconsin biology teachers. The American Biology Teacher, 51, 200-202. doi: 10.1371/journal.pbio.0060124

Van Oorschot, F., \& Ziermann, S. (Eds.), Theologie in Übersetzung? Leipzig: Ev. Verlagsanstalt.

Winograd, K. (2009). An exploratory study of race and religion in the emotional experience of Afro-American female teachers. In P. A. Schutz \& M. Zembylas (Eds.), Advances in teacher emotion research. The impact on teachers' lives (pp. 299-321). New York: Springer US. 